MARIMUTHU MUNIEN V BMW FINANCIAL SERVICES (SA) (PTY) LTD UNREPORTED

CASE NO 16103/08 (KZD)

ISSN 1727-3781

2009 VOLUME 12 No 4 


\section{MARIMUTHU MUNIEN V BMW FINANCIAL SERVICES (SA) (PTY) LTD UNREPORTED CASE NO 16103/08 (KZD)}

\section{CM van Heerden ${ }^{*}$ and $\mathrm{H}$ Coetzee ${ }^{* *}$}

\section{Introduction}

Section 129(1)(a) of the National Credit $A c t^{1}$ provides that, as a required procedure before debt enforcement -

[i]f the consumer is in default under a credit agreement, the credit provider:

(a) may draw the default to the notice of the consumer in writing and propose that the consumer refer the credit agreement to a debt counsellor, alternative dispute resolution agent, consumer court or ombud with jurisdiction, with the intent that the parties resolve any dispute under the agreement or develop and agree on a plan to bring the payments under the agreement up to date.

Despite the use of the word 'may' in section 129(1)(a), it is clear, on a proper reading of section 129(1)(a) together with sections 129(1)(b), 130(1) and 130(3) of the NCA, that compliance with the requirements of section 129(1)(a) prior to actual debt enforcement in a court is mandatory. ${ }^{2}$

Section 129(1)(a) contains no indication of any time limits applicable to the section itself. Clarity on this aspect is, however, provided for by section 130(1)(a), which stipulates that the consumer must be in default under the credit agreement for at least twenty business days and that at least ten business days must have elapsed since the credit provider delivered the

* Corlia van Heerden. BLC LLB LLM LLD, Associate Professor, University of Pretoria. Associate Professor of Law, University of Pretoria.

** Hermie Coetzee. B Com (Law) LLB, Lecturer, University of Pretoria.

1 National Credit Act 34 of 2005 (hereinafter the NCA).

2 Scholtz et al Credit Act par 12.4.2. 
section 129(1)(a) notice to the consumer before the credit provider will be entitled to approach a court to enforce the agreement. ${ }^{3}$ It is submitted by Otto that these two periods may run simultaneously. ${ }^{4}$

Section 129(1)(a) is further silent as to the method by which the default should be brought to the consumer's notice. Section 130(1)(a), however, provides clarity by requiring the section 129(1)(a) notice to be delivered.

From the aforesaid provisions it appears that a credit provider who fails to comply with the provisions of section 129(1)(a) prior to debt enforcement by means of litigation will be in a procedural predicament as the credit provider will not possess a complete cause of action thus, for instance, rendering the summons excipiable. If it is clear that the credit provider has not adhered to the provisions of section 129(1)(a), an exception on the basis of failure to disclose a complete cause of action will be upheld with the effect that the summons will be set aside with costs. If there was indeed compliance with section 129(1)(a) but merely a failure to make an allegation to this effect in the summons, the problem can be remedied by a subsequent amendment.

The crucial question thus appears to be whether or not in a given situation one may say that there was proper compliance with section 129(1)(a), as this directly affects the existence or absence of a complete and proper cause of action. In order to address this question, a number of factors has to be considered, namely:

(a) Was the notice contained in writing as required by section 129(1)(a)?

(b) Did the contents of the notice reflect:

(i) the consumer's default; 
(ii) a proposal that the consumer refer the credit agreement to a debt counsellor, alternative dispute resolution agent, consumer court or ombud with jurisdiction;

(iii) that the intent of the notice is that the parties resolve any dispute under the agreement or develop and agree on a plan to bring the payments under the agreement up to date?

(c) Did the notice require the consumer to respond thereto within ten business days after delivery or to indicate that it rejects the credit provider's proposals?

(d) Did the notice inform the consumer that, should the consumer fail to respond to the section 129(1)(a) notice or reject the proposals contained therein and should the consumer remain in default for twenty days since the consumer's default commenced, the credit provider may elect to cancel the agreement and proceed with litigation to enforce the credit provider's rights under the credit agreement?

(e) Was the section 129(1)(a) notice duly 'delivered'?

(f) Was the section 129(1)(a) notice delivered to the correct address for purposes of the NCA?

Compliance with (a) to (d) above seems relatively straightforward and will appear ex facie the notice. However, it appears that the concept of 'delivery' of the section 129(1)(a) notice is problematic. In this regard there seems to be uncertainty regarding two main issues, namely:

(a) When exactly can it be said that a section 129(1)(a) notice was 'delivered' for purposes of the NCA?

(b) Is it necessary for such a notice to be received by the consumer in order to constitute proper compliance with the delivery requirement pertaining to section $129(1)(a)$ ?

The word 'delivery' is unfortunately not defined in the NCA, despite its being used in numerous provisions. ${ }^{5}$ It is, however, defined in the regulations ${ }^{6}$ as: 
[U]nless otherwise provided for ... sending a document by hand, by fax, by e-mail, or registered mail to an address chosen in the agreement by the proposed recipient, if no such address is available, the recipient's registered address.

Further to the aforesaid, section 65(1) of the NCA provides that every document that is required to be delivered to a consumer must be delivered in the prescribed manner, if any. Section 65(2) provides that, if no method has been described for the delivery of a particular document to the consumer, the person required to deliver that document must:

(a) make the document available to the consumer through one or more of the following mechanisms -

(i) in person at the business premises of the credit provider, or at any other location designated by the consumer but at the consumer's expense, or by ordinary mail;

(ii) by fax;

(iii) by email; or

(iv) by printable web-page and

(b) deliver it to the consumer in the manner chosen by the consumer from the options made available in terms of paragraph (a).

Although the NCA does not contain a definition of 'delivery' it does define 'prescribe' as "prescribed by regulation" and it defines 'regulation' as "a regulation under this Act", thus having the effect that the words "in the prescribed manner" as used in section 65(1) appear to refer to the manner of delivery prescribed in regulation $1 .^{7}$

With regard to section 129(1)(a) the following problematic issues arise. Firstly, the section itself does not specify a specific method of delivery. Secondly the NCA itself does not contain a definition of 'delivery' that can shed light on the exact meaning of 'delivery' and the closest indication to a possible method of delivery for purposes of section 129(1)(a) appears to be section 65(1), which 
appears to provide for delivery as prescribed by regulation. Thirdly, it is submitted that it is uncertain if one can merely regard the section 129(1)(a) notice as a 'document' for purposes of applying either section 65(1) or section $65(2)$ to it in order to solve the problem regarding delivery. It is further submitted that given the serious implications of a failure to respond to a section $129(1)(a)$ notice, namely that it can result in costly enforcement steps being taken against the consumer, two methods of service in section 65(2) militate against the mere application thereof to delivery of a section 129(1)(a) notice, namely delivery by ordinary mail (of which there would be no proof) and by printable web-page. The fact that the NCA also fails to define the word 'document' obviously does not aid in this interpretational predicament.

A further section that appears relevant in this context is section 96, which deals with the address for notice, which is also a matter on which section 129(1)(a) is conspicuously silent. Section 96 significantly indicates that -

(1) [w]henever a party to a credit agreement is required or wishes to give legal notice to the other party for any purpose contemplated in the agreement, this Act or any other law, the party giving notice must deliver that notice to the other party at -

(a) the address of that other party as set out in the agreement, unless paragraph (b) applies; or

(b) the address most recently provided by the recipient in accordance with subsection (2).

It should be noted that whereas section 65 deals with the method of delivery without specifying the address for delivery, section 96 deals with the address for delivery but does not elaborate on how such delivery must occur. However, there appears to be an important distinction between the two sections in the sense that section 65 specifically refers to 'documents' whereas section 96 specifically refers to 'legal notice', a term that is also not defined in the NCA. One may consequently ask what the significance of this distinction is - was it drawn inadvertently or was it drawn with the intention of indicating that for purposes of the NCA there is a distinction between a document and a legal notice? One may then further ask, for purposes of dealing with the concept of 'delivery' - does the notice in terms of section 129(1)(a) constitute a 'document', 
thus allowing section 65 to be applied to it, or does it strictly constitute a 'legal notice'? This question is relevant since section $129(1)(a)$ specifically uses the term 'notice' and its mandatory pre-litigation status would justify regarding it as a 'legal notice'. 8

Should the point of departure be that the word 'document' should be given its wide and ordinary meaning, it is submitted that this 'document' can include a legal notice. However, if the term is understood in such a limited fashion as to exclude the 'legal notice' which is specifically provided for but not defined in the NCA, then the predicament is that the NCA does not specify the method of delivery of a legal notice, and section 65(1) (and by implication regulation 1) cannot be used to cure such defect as it can be used only with regard to a 'document'.

Another section that might possibly be considered in determining the issues regarding delivery of the section $129(1)(a)$ notice is section 168 , which provides:

Unless otherwise provided in this Act, a notice, order or other document that, in terms of this Act, must be served on a person will have been properly served when it has been either -

(a) delivered to that person; or

(b) sent by registered mail to that person's last known address.

Neither section 129(1)(a) nor any other section referring to it contains any indication that the said notice has to be served. In fact it appears that the word 'serve' is very sparsely used in the NCA, appearing only in section 152 in the context of service of decisions, judgments or orders of the Tribunal. However, from section 168(a) it appears that service of a notice is actually equated with delivery. If 'deliver' refers to delivery as per regulation 1 , it is strange that the legislature has provided in section 168 that proper service occurs if the notice, order or document is delivered or sent by registered post, as the latter is 
already included in the definition of delivery. In conclusion, given that meaning of 'served' for purposes of the NCA appears to be no wider than that of 'deliver', it is clear that it is pivotally significant to determine how delivery of a section 129(1)(a) notice should occur in order to determine whether or not there was proper compliance with the NCA.

\section{Facts of the case}

The problematic issue of delivery of a section 129(1)(a) notice and the question of whether or not such notice has to be received by the consumer to constitute proper compliance with section 129(1)(a) was recently addressed in the as yet unreported decision of Marimuthu Munien v BMW Financial Services (SA) (Pty) Ltd. ${ }^{9}$ The facts were that on 8 March 2006 the applicant and first respondent entered into an instalment sale agreement in respect of a vehicle. During mid 2008 the applicant fell into arrears with his monthly payments. Summons was served on the applicant's domicilium citandi et executandi and on 6 February 2009 default judgment was granted against the applicant, including an order to return the vehicle. ${ }^{10}$

The applicant sought rescission of the judgment and aimed at restraining the first respondent from repossessing the vehicle, pending the decision relating to the rescission of the default judgment, with the current application. The applicant intended to apply for rescission on the basis that he had not received the summons as he no longer resided at the address, and that he had a good defence, namely that the first respondent did not comply with section 129(1)(a) of the NCA.

9 Marimuthu Munien v BMW Financial Services (SA) (Pty) Ltd Case no 16103/08 (KZD) (as yet unreported) - all references to the decision are to the typed manuscript (hereinafter the Munien case).

10 Munien (n 9) par 1. 
In casu, the section 129(1)(a) notice was sent by means of registered post to the applicant's chosen domicilium. ${ }^{11}$ The applicant's argument of noncompliance was, however, founded on the allegation that there is no street delivery of mail at the specific address and that the notice could therefore never be delivered to him. ${ }^{12}$ Wallis $\mathrm{J}$ formulates the primary focus of the argument as:

... letters sent by registered post to street addresses such as that chosen by the applicant as his domicilium would not be received because of the absence of a delivery service in that area. ${ }^{13}$

The applicant argued that, keeping the purposes of the NCA in mind, the notice must be received by the consumer before there will be compliance with section 129(1)(a). The argument was based on the wording of section 129(1)(b) and 130(1) stating that enforcement proceedings may commence only after "first providing ... to the consumer" a section 129(1)(a) notice and that the notice must be "delivered ... to the consumer". From these extracts the inference was drawn that the wording of section 129(1)(a), namely "draw the default to the notice of the consumer in writing" means that it must be received to be effective. ${ }^{14}$ The basis of the argument was that the NCA does not prescribe, unlike section 5(4) of the Credit Agreements Act, ${ }^{15}$ that the address chosen by the consumer would be the domicilium for all purposes. On the construction of the words quoted from sections 129 and 130 it was submitted that the notice had to come to the attention of the consumer to be effective. ${ }^{16}$ Wallis $\mathrm{J}$ decided that this assumption is incorrect and reverted to subsections 65(1) and 65(2) as referred to by the respondent.

The respondent contended that the manner of delivery has been prescribed in the regulations ${ }^{17}$ in terms of the NCA and that section 65(1) therefore applies to

11 Munien (n 9) par 3.

12 Munien (n 9) par 4.

13 Ibid.

14 Munien (n 9) par 5.

15 Credit Agreements Act 75 of 1980.

16 Munien (n 9) par 6.

17 GN R489 in GG 28864 of 31 May 2006. 
the section 129(1)(a) notice. ${ }^{18}$ Wallis $\mathrm{J}$ remarked that this contention is not necessarily correct as regulation 1, containing the definitions, commences with the wording: "In these Regulations, any word or expression defined in the Act bears the same meaning as in the Act ...". Written submissions were presented by counsel on this aspect, the applicant being of the opinion that the definitions in the regulations are not applicable and that the matter fell under section 65(2) of the NCA. The respondent, however, persisted that the definition in the regulations applied. ${ }^{19}$

The respondent based his arguments on the heading to the regulations, namely "Interpretation and Application of the Act". Section 1 of the NCA further defines the Act as including the regulations and therefore it will be absurd to conclude that certain methods of delivery are prescribed in terms of section 65(2) and other methods of delivery in terms of the regulations. Further, there are only a few references to the words 'deliver' or 'delivered' in the regulations and in most of those instances a specific manner of delivery is prescribed, rendering the definition of 'delivered' superfluous in those instances. Section 65, however, makes it clear that when a notice must be sent it must be delivered as provided for in the particular section, and section 65 will necessarily apply to section $129(1)(a) .{ }^{20}$ The respondent argued that whilst the opening wording in the regulations points to limited application of the definitions it must be seen in context, and derived therefrom that the intention was to prescribe the modes of delivery in terms of section 65(1). ${ }^{21}$ It was asked why the Minister would define delivery for the very limited purposes in the regulations only, when a greater need exists in the NCA itself. The respondent further pointed out that other expressions, such as 'auditor' and 'debt counsellor', are defined in the regulations but not in the NCA, and that in those instances the expressions carry the same meaning in both the NCA and the regulations. ${ }^{22}$

18 Munien (n 9) par 8.

19 Ibid.

20 Munien (n 9) par 9.

21 Munien (n 9) par 10.

22 Ibid. 
Wallis $\mathrm{J}$ remarked that there was merit in the submissions by the respondent. He said that there is no reference to section 65(1) or to 'prescribed' in the definition of 'delivered' contained in the regulations, but that the NCA does not require reference to the empowering provision. He further indicated that the "form of a definition" is not the best manner to prescribe modes of delivery, but that the heading of the regulations specifically states that it is meant to be an interpretation of the NCA. It was thus held that the regulations contain a stricter mode of delivery, namely registered mail, and that there would be no reason for the Minister to prescribe stricter modes for "relatively minor issues", but not so where section $129(1)(a)$ is applicable, thus causing him on this basis to find in favour of the respondent. ${ }^{23}$

Accordingly, Wallis $\mathrm{J}$ decided that the manner of delivery was prescribed in the NCA, but the method was prescribed in the regulations as opposed to section 65(2). He pointed out that the regulations state that a document is delivered if sent by one of four methods, and therefore a section 129(1)(a) notice is delivered if sent by registered post to the address chosen by the consumer, irrespective of whether or not it actually came to the attention of the consumer. It is thus the sending of the document that amounts to delivery and not the receipt thereof. He held that it is only logical that this should be the case, as it would be impossible for the sender to make sure that the notice had been received, for instance where it was sent by fax or by e-mail. In other instances such as registered mail, there is no guarantee that the notice would actually be received. Wallis $\mathrm{J}$ further stated that if it had been the legislature's intention that the notice had to be received and had to come to the attention of the consumer, it would have been relatively easy to expressly state it in that manner. ${ }^{24}$

The court further indicated that its interpretation was in line with those of the NCA's predecessors. It referred to section $12(b)$ of the Hire-Purchase Act, ${ }^{25}$ which stated that a seller should not commence enforcement of the agreement 
... unless he has made written demand to the buyer to carry out the obligation in question ... and the buyer has failed to comply with such demand.

It also referred to Weinbren $v$ Michaelides, ${ }^{26}$ wherein it was decided that receipt of the relevant notice was necessary, whereafter the wording of the section was changed to read:

... unless he has by letter handed over to the buyer or sent by registered post to him at his last known residential business address, may demand to the buyer .... .

The court pointed out that as a result of legislative amendment, it was decided in Fitzgerald $v$ Western Agencies ${ }^{27}$ that the handing over or posting by registered mail relieved the seller of this obligation. Subsequently in Marques $v$ Unibank $L t d,{ }^{28}$ which was decided under the Credit Agreements Act, ${ }^{29}$ it was also held that there would be compliance with the relevant notice in terms of the CAA if the notice was send by registered mail to the domicilium address. ${ }^{30}$

Wallis $\mathrm{J}$ considered the purposes of the NCA, but contended that they should not alter the plain meaning of the wording in the definition of 'delivered'. He stated that the question is not so much as to the policy and purpose of the NCA but of striking a balance between a credit provider and a consumer. A person sending a notice has little further control over the matter, and limited ways of ensuring that the notice was indeed received. A credit provider will not know of a change of address unless informed thereof by the consumer, and it would further be reasonable of a credit provider to expect that delivery of mail does take place at the address provided by the consumer. He also stated that the costs of actually ascertaining that the notice reached its destination would be substantial and eventually be carried by the consumer. According to him, nothing in section 3 is inconsistent with the interpretation that a credit provider 
fulfils the obligation of delivering the section 129(1)(a) notice if it is sent by registered post, fax or email to the address or number as provided by the consumer. ${ }^{31}$

The court thus held that the above interpretation is fatal to both the applicant's arguments of non-compliance with section 129(1)(a). The first argument that the address chosen in the agreement is not one where postal delivery takes place failed on the basis that the sending and not the receipt of the notice amounts to delivery. The second argument based solely on non-receipt also failed for the same reasons. ${ }^{32}$

Wallis $\mathrm{J}$ held that even if his conclusion, that the regulations prescribe the manner of delivery, is incorrect and that the manner of delivery has in fact been prescribed in terms of section 65(2), the present application would still fail for the following reasons: ${ }^{33}$

Section 65(2) contains two elements, the first being that the credit provider should make the document available to the consumer through one of the mechanisms listed in the subsection. ${ }^{34}$ Secondly, the document should be delivered in the manner chosen by the consumer. ${ }^{35}$ The consumer will usually choose the manner in the credit agreement, as was the case in the present matter, ${ }^{36}$ where the notice was sent by registered mail to the chosen address. Wallis $\mathrm{J}$ formulates the question that needs to be answered as: ${ }^{37}$

whether the fact that the notice was not received or indeed, that the notice could never have been received because there is no postal service to residences situated in that area, means that the first respondent did not comply with section 129(1)(a).

36 Munien (n 9) par 18 and 19. $\mathrm{Cl} 15.2$ of the credit agreement provided that: "any notice delivered by hand or sent by registered post to Purchaser's domicilium shall be deemed to have been received, if delivered by hand, on date of delivery or was sent by registered post, on the third day after date of posting". 
The question is answered in the negative. Wallis $\mathrm{J}$ held that it is not merely required that delivery should take place, but delivery in the manner chosen by the consumer. Due thereto that the consumer chooses the manner, he should bear the risk of non-receipt thereof. The judge remarked that the methods of electronic communication may be generally reliable and speedy methods of communications, but that it is not a given that messages sent via such a medium will be received. It would therefore be difficult for the sender to ascertain if such messages were received and to prove receipt if disputed. ${ }^{38}$

The court remarked that even though a consumer may choose for the notice to be made available at any location designated by the consumer at the consumer's own expense, it would be inconvenient to the credit provider and recovery of the expense may be difficult as the consumer is already in arrears. If a consumer is able to allege that the notice was available at the location, but did not come to the consumer's attention, the situation would be 'intolerable', and on this basis it was held that it could never have been intended by the legislature that the notice should come to the consumer's attention. ${ }^{39}$

Thus it was decided that if a credit provider delivered the notice in the manner chosen by the consumer from the options available under section 65(2)(a), it would be irrelevant whether the notice actually came to the attention of the consumer. The consumer chooses the manner of delivery and should be reasonably sure that it would come to the consumer's attention. The court remarked that in the present case the consumer was most probably aware of the deficiency in the address and further should have altered his domicilium when he moved. He was entitled to alter his address both in terms of the agreement and section 96 of the NCA. He further did not inform the credit provider of the new location of the vehicle as is required by section 97 of the 
NCA, and consequently it was held that the consumer himself is largely to blame for the notice and summons not coming to his attention. ${ }^{40}$

Wallis $\mathrm{J}$ further stated that he reached his conclusion on the basis of the structure and language of the NCA alone, as he had not been referred to case law pertaining to the precise issue at hand. However, he had referred to decisions under other legislation or rules dealing with similar provisions. Reference was made to Vessels $v$ Brink,${ }^{41}$ where a rule dealing with execution was considered. It provided that a notice

... shall be served by means of a registered letter, duly prepaid and posted, addressed to the person intended to be served.

In the Vessels-case it was decided that the return of the notice as undelivered was immaterial as long as it was given in the prescribed manner. ${ }^{42}$

Wallis $\mathrm{J}$ also referred to section 19(2)(b) of the Alienation of Land Act ${ }^{43}$ which prescribes notification to the purchaser of breach of contract prior to enforcing the agreement. The notice may also demand rectification of such a breach. Section 19(2) was quoted, which provides that:

A notice referred to in $s$ (1) shall be handed to the purchaser or shall be sent to him by registered post to his address referred to in $\mathrm{s} 23$ and shall contain:

(a) $\ldots$

(b) a demand that the purchaser rectify the alleged breach within a stated period, which, ... shall not be less than thirty days calculated from the date on which the noticed was handed to the purchaser or sent to him by registered post, as the case may be ...

40 Munien (n 9) par 22.

41 Vessels v Brink 1950 (4) SA 352 (T).

42 Munien (n 9) par 23.

43 Alienation of Land Act 68 of 1981. 
Reference was also made to Van Niekerk $v$ Favel, ${ }^{44}$ where section 19(2) was considered and it was decided that the requirement of notification was satisfied if the letter was sent by registered post, irrespective of whether it was received or not. ${ }^{45}$

The court remarked that even though the cases referred to are not in pari materia with section 65(2), it illustrates that in general when a statute or rule requires a notice to be given in specified ways, it is sufficient to follow the procedure and irrelevant whether it actually comes to the attention of the recipient. Wallis $\mathrm{J}$ decided that this approach is in line with section 65(2) specifically because the consumer may now choose the method by which the notice must be sent. He stated that even though the consumer has little opportunity to choose the method in standard contracts, a consumer will be able to change the method if not suitable. Further, the consumer has the duty to update the consumer's details with the credit provider should there be a change of address. According to Wallis $J$ the clear intention of section 65(2) is that it would be sufficient for a credit provider to send the notice to the address provided by the consumer. Again, it would be irrelevant whether it actually reaches the consumer or not. ${ }^{46}$

Even though registered mail is not one of the options listed in section 65(2), the court held that it remains a postal service, that the use of registered mail makes it more likely, not less, that the recipient will receive such notice, and thus it held that a notice sent by registered mail will effect compliance with section $65(2) .{ }^{47}$

In conclusion, it was found that the respondent complied with the provisions of sections 129(1)(a), 65 as well as 130, and that the applicant therefore does not

\footnotetext{
44 Van Niekerk v Favel 2006 (4) SA 548 (W).

45 Munien (n 9) par 24.

46 Munien ( $\mathrm{n}$ 9) par 25. In this regard he indicted that the fact that in the present case a contract of adhesion was considered does not change the situation.

47 Munien (n 9) par 26.
} 
have reasonable prospects of succeeding in an application for rescission of judgment. The application was dismissed with costs. ${ }^{48}$

\section{$3 \quad$ Analysis}

\subsection{Absence of domicilium provision}

The essential question that had to be addressed in casu was if a section $129(1)(a)$ notice is delivered if it is sent by registered post to an address selected by the consumer, irrespective of if it is capable of being delivered at that address and if it comes to the attention of the consumer. ${ }^{49}$ The first issue that was raised in an attempt to answer this question, namely that the NCA does not contain any provision such as that embodied in its predecessor the CAA, which provided that an address chosen by the consumer would for all purposes under the CAA serve as the consumer's domicilium citandi et executandi, ${ }^{50}$ deserves further scrutiny. ${ }^{51}$ In Marimuthu Munien $v$ BMW Financial Services (SA) (Pty) Ltd it was submitted on behalf of the consumer that the effect of the lack of such a provision in the NCA is that the section $129(1)(a)$ notice has to come to the attention of the consumer, i.e. must by received by the consumer.

It can be pointed out that although the NCA does not provide in specific words that the address chosen by the consumer in the agreement will serve as a

48 Munien (n 9) par 27, 28 and 29.

49 The Munien-judgment was approved of in the unreported Eastern Cape case of Firstrand Bank v Bernardo Case no 608/09, (where the court added that by virtue of the definition of 'served' in s 7 of the Interpretation Act 33 of 1957, 'delivery' of the s 129 notice does not mean that it has to be received by the defendant) as well as in the unreported case of ABSA Bank Limited $v$ Kritzinger Case no 6474/2009 in the Western Cape High Court. It is also important to note that although certain issues pertaining to delivery of the $s$ 129(1)(a) notice were addressed in ABSA Bank Ltd v Prochaska t/a Bianca Cara Interiors 2009 (2) SA 512 (D \& CLD), the said case is distinguishable from the Munien-decision as it did not address the meaning of 'delivery' for purposes of $s$ 129(1)(a) or the question of whether or not receipt of the $s$ 129(1)(a) notice by the consumer is essential. In the Prochaska-case (on 524J-525S) the court held that when a domicilium address is chosen by the consumer, the credit provider must ensure that the address to which the $s$ 129(1)(a) notice is sent is similar in every respect to the chosen domicilium address.

50 S 5(4).

51 Munien (n 9) par 6. 
domicilium address, this is most probably only as a result of employing plain language, ${ }^{52}$ and the fact that the NCA aims to protect consumers who suffer literacy disadvantages. ${ }^{53}$ Section 96 of the NCA is most probably the provision that best mirrors section 5(4) of the repealed CAA. As section 65 contains no provision relating to an address for delivery, it is submitted that the legislature most probably intended sections 65 and 96 to be read together. It is interesting, though, that Wallis $\mathrm{J}$ based his proposition that the NCA does in fact contain a provision that counteracts the submission on behalf of the defendant (relating to the absence of a domicilium provision in the NCA) on the existence of section 65 rather than on section 96 . This is strange as section 65 provides for the consumer's right to receive documents but does not make any mention of an address for delivery, whereas section 96 deals specifically with the address for delivery of a legal notice. From section 96 it is clear that delivery of a legal notice should occur at the address of the party as set out in the agreement, and it is submitted that for all practical purposes such an address fulfils the function of a domicilium address, which is to facilitate delivery or service of documents, processes and notices. Furthermore, when one has regard to the unlawful provisions contained in section 90 of the NCA, no mention is made that a provision in a credit agreement in which an address is chosen as a domicilium address is unlawful. The inference would thus be that even if it can be argued that the NCA does not contain a specific domicilium provision, nothing in the NCA prevents a credit provider from specifically providing in a credit agreement that the address chosen by the consumer in the agreement ${ }^{54}$ will serve as a domicilium address.

It should also be noted that section 5(4) of the CAA provided that the domicilium address chosen in accordance with section 5(4) could be changed in a written communication delivered by hand or registered mail. This provision is mirrored by section 96(2) of the NCA which provides that a party to a credit agreement may change an address by delivering to the other party a written

52564.

53 S 3(a). See also Scholtz et al (n 2) par 12.4.8.

$54 \mathrm{~S} 96$. 
notice of the new address by hand, registered mail or electronic mail, if that party has provided an e-mail address. It is ironic, however, that whereas section 96(1) is silent on the exact mode of delivery, and does not even state that it should occur in the 'prescribed' manner, section 96(2) sets out three different methods of delivery in respect of a change of address, thus creating legal certainty as to how the notice of change of address should be delivered. ${ }^{55}$ In the context of Marimuthu Munien v BMW Financial Services (SA) (Pty) Ltd though, it should be noted that the consumer in fact, in terms of clause 15.2 of the credit agreement with the credit provider, ${ }^{56}$ chose the address that he furnished in the agreement as domicilium address. Even though the agreement was concluded under the repealed CAA, it is submitted that such a clause did not subsequently become invalid as a result of the coming into operation of the NCA. It should further be noted that even on the interpretation that the court afforded the term 'delivery' as contained in section 65(1), namely that it refers to 'delivered' in terms of regulation 1 , it is required that delivery occurs at the address chosen in the agreement by the consumer. Thus, the choice of a domicilium address in an agreement does not appear to be at odds with the provisions of section 96 , or for that matter, regulation 1.

It is thus submitted that the effect of regulation 1's requiring delivery of a 'document' at the address chosen in the credit agreement as well as the effect of section 96(1)'s requiring delivery of a 'legal notice' at the address as chosen in the credit agreement is to facilitate delivery or service of documents, processes and notices and that, for all practical purposes, the address chosen in the credit agreement serves as an implied statutory domicilium address, as the NCA specifically obliges delivery at such address. To hold the contrary would be severely prejudicial to a credit provider, who would then in many instances have to incur extensive costs and experience severe delay in tracing a consumer who has left the address in the agreement without notifying the credit provider in accordance with the provisions of section 96(2). In certain

55 This despite the fact that reg 1 GN R489 in GG 28864 of 31 May 2006 purports to describe a general method of delivery applicable in all instances.

56 Which qualifies as a pre-existing credit agreement, as it was entered into prior to 1 June 2007. 
instances a credit provider may even face prescription of a claim if the credit provider is unable to trace such a consumer. It is thus only equitable, given that Wallis $\mathrm{J}$ held that a balance should be struck between the rights of credit providers and consumers, ${ }^{57}$ that the address chosen by the consumer serves as the consumer's domicilium address.

\subsection{Application of Regulation 1}

It is submitted that the reasoning and motivation of Wallis $\mathrm{J},{ }^{58}$ that 'delivery' for purposes of section 65(1) of the NCA means that the document has to be delivered in accordance with regulation 1, is correct. However, as pointed out by Mills, the same conclusion could have been reached via a much shorter route provided for in section 1 of the NCA, which defines the word 'prescribe' to mean "prescribed by regulation". 59

\subsection{Receipt of delivered document}

As pointed out by Otto, the question of whether or not a document that is required to be delivered in terms of an NCA has to come to the attention of the recipient to be effective has been dealt with by our courts on various occasions. In Fitzgerald $v$ Western Agencies ${ }^{60}$ it was decided that a notice sent in terms of the Hire Purchase $A c t^{61}$ was still effective provided it had been sent in accordance with the Act. ${ }^{62}$ However, a contrary view was held with regard to the Sale of Land on Instalments Act, ${ }^{63}$ in Maron v Mulbarton Gardens (Pty) Ltd, where it was decided that the word 'inform' in section 13 of that Act implied that the notice had to reach the purchaser. ${ }^{64}$ This decision was not followed by the court in Maharaj v Tongaat Development Corporation (Pty) Ltd. ${ }^{65}$ However,

\footnotetext{
57 Munien (n 9) par 14. See also s 3(d).

58 Munien (n 9) par 9 -11.

59 See Mills 2009 De Rebus 26.

60 Fitzgerald $v$ Western Agencies 1968 (1) SA 228 (T).

61 Hire Purchase Act 36 of 1942.

62 Otto (n 4) 89.

63 Sale of Land on Instalments Act 72 of 1971. The Act was repealed by the Alienation of Land Act 68 of 1981.

64 Maron v Mulbarton Gardens (Pty) Ltd 1975 (4) SA 123 (W) 125 D.

65 Maharaj v Tongaat Development Corporation (Pty) Ltd 1976 (1) SA 314 (D) 318 E.
} 
when Maharaj v Tongaat Development Corporation (Pty) $L t d^{66}$ was taken on appeal, ${ }^{67}$ the Appellate Division favoured the view that the notice must reach the purchaser, but did not base its decision on the meaning of 'inform'. In Holme $v$ Bardsley $^{68}$ the court followed the position in Maron $v$ Mulbarton Gardens. ${ }^{69}$ Holme $v$ Bardsley ${ }^{70}$ was decided under section 19 of the Alienation of Land Act, ${ }^{71}$ which section originally also provided that the purchaser had to be 'informed' of the purchaser's breach of contract. However, following an amendment by the Alienation of Land Amendment Act, ${ }^{72}$ the word 'inform' was replaced with 'notify' in an apparent attempt to make receipt of the notice unnecessary. ${ }^{73}$

Otto consequently submitted that the decision in Holme $v$ Bardsley ${ }^{74}$ is wrong as it cannot be laid down as an absolute rule that the notice must under all circumstances reach the consumer. ${ }^{75}$ He proposed that the better view is that the credit provider has complied with the requirements of the legislation if the credit provider has meticulously followed the technical requirements of the particular section even though the notice may not reach the credit receiver. ${ }^{76}$ The Full Bench of the Witwatersrand Local Division of the High Court referred with apparent approval in Marques $v$ Unibank $^{77}$ to the opinions expressed by Otto regarding section 11 of the CCA, rejected the decision in Holme $v$ Bardsley, ${ }^{78}$ and held that the notice does not necessarily have to come to the attention of the credit receiver. ${ }^{79}$ In the context of compliance with section

66 Ibid.

67 Maharaj v Tongaat Development Corporation (Pty) Ltd 1976 (4) SA 994 (A).

68 Holme v Bardsley 1984 (1) SA 429 (W).

69 Maron v Mulbarton Gardens (Pty) Ltd 1975 (4) SA 123 (W) 125 D.

70 Holme v Bardsley 1984 (1) SA 429 (W).

71 Alienation of Land Act 68 of 1981.

72 Alienation of Land Amendment Act 51 of 1983.

73 Otto (n 4) 90.

74 Holme v Bardsley 1984 (1) SA 429 (W).

75 Otto Consumer Credit par 62.

76 Ibid.

77 Marques v Unibank 2001 (1) SA 145 (W).

78 Holme $v$ Bardsley 1984 (1) SA 429 (W).

79 Otto 2001 JSAL 169. 
129(1)(a), Otto subsequently submitted that the court should follow the decision in Marques $v$ Unibank. ${ }^{80}$

Having regard to the express wording of the definition of 'delivery' in regulation 1 , it is clear that the legislature intended the mere sending of a document in accordance therewith by registered post, fax or e-mail to constitute compliance with the delivery requirement. It can be agreed with Wallis $\mathrm{J}^{81}$ that the sender employing any of these divergent methods of delivery would have no certain means of establishing that the notice has been received and furthermore that, had the Minister the intention that the notice should be received and come to the attention of the consumer, a rule to that specific effect could easily have been formulated.

As pointed out in paragraph 1, section 130(1)(a) stipulates that at least ten business days must have elapsed since the credit provider delivered the section 129(1)(a) notice before such a credit provider may approach a court to enforce the agreement. ${ }^{82}$ Section $2(5)$ provides that -

[w] hen a particular number of business days is provided for between the happening of one event and another, the number of days must be calculated by -

(a) excluding the day on which the first such event occurs;

(b) including the day on or by which the second event is to occur; and

(c) excluding any public holiday, Saturday or Sunday that falls on or between the days contemplated in paragraphs (a) and (b) respectively.

As the sending of a document constitutes delivery thereof, it is submitted that the ten business days applicable to section 129(1)(a) will start running on the first business day after which the document was sent. ${ }^{83}$

80 Marques v Unibank Ltd 2001 (1) SA 145 (W). See Otto (n 4) 90.

81 Munien (n 9) par 12.

82 Provided that the consumer has been in default for at least twenty business days.

83 See s 2(5) of the NCA. 


\subsection{The alternative interpretation}

In view of the decision that the definition of 'delivered' in regulation $1^{84}$ applies to the term 'delivered' as provided for in section 65(1)(a) of the NCA, it is submitted that section 65(2) appears superfluous, as the method of delivery of a document will thus always be prescribed in accordance with the provisions of regulation $1^{85}$ and a credit provider would not need to resort to the options provided for in section 65(2). However, Wallis $\mathrm{J}$ indicated that even if he were wrong in his initial interpretation regarding regulation 1 and section 65(2) did in fact apply this would not have availed the applicant as the consumer would have had the option to choose the method of delivery of the relevant document. The options would most likely have been dealt with in the agreement, which would cause the risk of non-receipt to lie with the consumer, as the consumer would have chosen the method of delivery. It can be agreed with Wallis $\mathrm{J}$ that should section 65(2) be applicable in a given situation, the consumer should carry such risk of non-receipt due to the consumer's freedom of choice. This opinion is sensibly motivated, ${ }^{86}$ and is also supported by Otto. ${ }^{87}$ On this construction, the court appears to be correct in indicating ${ }^{88}$ that if a credit provider delivered the notice in the manner chosen by the consumer in the agreement, and that manner was one specified in section 65(2)(a), it is irrelevant whether or not the notice in fact came to the attention of the consumer. The issue, however, still remains that, as a result of applying regulation 1 to 'delivered' in terms of section 65(1), it is uncertain exactly in which instances section 65(2) will apply. 


\section{Conclusion}

It is submitted that the NCA is clearly not an example of impeccable draftsmanship and the interaction between the NCA and the regulations in certain instances may strike one as odd, as it creates the impression that the legislature attempted to cure certain drafting problems in the NCA by providing for them in the regulations, especially insofar as definitions that one would have expected in the NCA are concerned. ${ }^{89}$

Given that the definition of 'delivery' in the regulations provides that it must occur at the address chosen in the agreement, one might also argue that it renders section 96(1)(a) superfluous, as the ordinary meaning of 'document' 90 would be wide enough to encompass a legal notice. It is submitted that if 'legal notice' were given a restricted meaning, that would have the result that section 96 would provide for an address for delivery of the legal notice but no method of delivery would be prescribed because regulation 1 and section 65(2) apply only to the delivery of 'documents'. It consequently leaves one with the impression that the legislature intended to distinguish between documents (as per regulation 1 , which deals with the delivery of documents) and legal notices (as per section 96, which provides for an address of delivery of a legal notice). However, the method of delivery of change of address provided for in section 96(2) is indicated in detail, appears to have general application, and is not restricted to applying only to the delivery of a legal notice. However, the inconsistency with which the legislature approaches the concept of delivery is clear from section 96 which, as pointed out, in itself contains three methods of delivery (not providing for delivery by fax) as opposed to the four methods (including fax delivery) provided for in regulation 1.

89 It appears that this matter for concern has been perpetuated in the Consumer Protection Act 68 of 2008, which also contains no definition of delivery but does contain a definition of 'prescribed' as "prescribed by regulation".

90 In the absence of a definition thereof in the NCA and regulations GN R489 in GG 28864 of 31 May 2006. 
It may be agreed with Wallis $\mathrm{J}^{91}$ that determining if a credit provider has complied with the NCA by sending a section 129(1)(a) notice by registered post involves answering the question of where the balance is to be struck between the credit provider and consumer when it comes to giving notices under the NCA. Because certain issues (such as whether the consumer has moved from the address given in the agreement or there is postal delivery at a street address that the consumer has provided) will usually fall within the exclusive knowledge of the consumer and would not be known to the credit provider unless the credit provider is so informed by the consumer, and because of the cost and time involved for a credit provider to ensure receipt of section 129(1)(a) notices by consumers, it seems only fair that the legislature intended the sending of a section 129(1)(a) notice by registered post, fax or e-mail to suffice for purposes of the NCA.

It is submitted that in the present instance the consumer's downfall was of his own making, as he contractually agreed, in clause 15.1 and 15.2 of the credit agreement, that the address that he chose could serve as domicilium citandi et executandi and that a notice could be delivered there by hand or registered post and would be deemed to have been received, if delivered by hand, on date of delivery or if sent by registered post, on the third day after the day of posting.

Apart from the fact that the consumer in casu provided a street address at which there was no postal delivery, it appears that he also moved from the address provided and failed to inform the credit provider thereof. In terms of section 97(2) of the NCA a consumer in respect of any goods is obliged to inform the credit provider of any change in the consumer's residential or business address in writing within ten business days after the change. ${ }^{92}$ Given that section 96(2) of the NCA read together with section 97(2) makes it clear that the consumer is obliged to give notice of a change in address in a specified manner, it is clear that a consumer who neglects to comply with the NCA in this 
regard cannot complain if a document, notice or summons is delivered at an address where such a consumer is no longer resident.

Although the way in which the legislature chose to deal with the concept of 'delivery' in the NCA and regulation thus leaves one with a slight feeling of unease and confusion, it is submitted that Munien $v$ BMW Financial Services (SA) (Pty) Ltd has at least brought legal certainty on one aspect, namely that regardless of whether regulation 1 or section 65(2) applies to delivery of a notice in terms of section 129(1)(a), ensuring that the notice has been received by the consumer, which would have placed an impossibly onerous burden on the credit provider, is not required for purposes of compliance with the delivery requirement in respect of section 129(1)(a).

It is further submitted that it would be prudent that a credit provider who enters into a credit agreement governed by the NCA, should such credit provider wish to provide in the agreement that the address chosen therein serves as domicilium citandi et executandi, should ensure that the agreement sets out clearly the meaning and effect of a domicilium address, given the plain language requirement in section 22 of the NCA.

It should further be noted that, apart from the difference between the specific methods of delivery provided for in regulation 1 and section 65(2) respectively, these provisions further differ in the sense that whereas section 65(2) specifically gives the consumer the right to choose the method of delivery regulation 1 does not, and it appears that the credit provider who complies with regulation 1 has the option to choose the method of delivery. However, as pointed out by Walllis $\mathrm{J},{ }^{93}$ the credit provider will usually in the credit agreement indicate and agree on the different methods of delivery with a consumer, and it would probably be prudent for a credit provider to pertinently draw the consumer's attention to the various possible modes of delivery. If the consumer then, for instance, chooses delivery by e-mail in the knowledge that he has no 
access to a computer, the consumer will be making the election at his own peril.

Finally, it is submitted that not all types of documents are of such a nature that they require service by hand or registered post as provided for in regulation 1. An example is a statement of accounts, which is usually forwarded to the consumer by ordinary post. Most probably the dichotomy between regulation 1 and section 65(2) could be cured by amending regulation 1 and section 65(1) to provide for the delivery of a legal notice, thus leaving section 65(2) to provide for the delivery of other documents. 


\section{Bibliography}

Mills 2009 De Rebus

Mills L "National Credit Act 34 of 2005 - Section 129 notice - dispatch or receipt?" 2009 De Rebus August 26

Otto 2001 JSAL

Otto JM "Kennisgewings van ontbinding by kredietooreenkomste en afbetalingskope van grond" 2001 (1) Journal of South African Law 169-176

Otto Consumer Credit

Otto JM Consumer Credit (LexisNexis Butterworths 1996)

Otto Explained

Otto JM The National Credit Act Explained (LexisNexis Butterworths Durban 2006)

Scholtz et al Credit Act

Scholtz JW et al Guide to the National Credit Act (LexisNexis Butterworths Durban 2008)

\section{Register of legislation and government documents}

Alienation of Land Act 68 of 1981

Alienation of Land Amendment Act 51 of 1983

Constitution of the Republic of South Africa 1996

Consumer Protection Act 68 of 2008

Credit Agreements Act 75 of 1980

GN R489 in Government Gazette 28864 of 31 May 2006

Hire-Purchase Act 36 of 1942

National Credit Act 35 of 2005

Sale of Land on Instalments Act 72 of 1971

\section{Register of court cases}

ABSA Bank Ltd v Prochaska t/a Bianca Cara Interiors 2009 (2) SA 512 (D\& CLD) 
ABSA Bank Limited v Kritzinger Case no 6474/2009 (WCH) (unreported)

Firstrand Bank v Bernardo Case no 608/09 (EC) (unreported)

Fitzgerald v Western Agencies 1968 (1) SA 228 (T)

Holme v Bardsley 1984 (1) SA 429 (W)

Maharaj v Tongaat Development Corporation (Pty) Ltd 1976 (1) SA 314 (D)

Maharaj v Tongaat Development Corporation (Pty) Ltd 1976 (4) SA 994 (A)

Marimuthu Munien v BMW Financial Services (SA) (Pty) Ltd Case no 16103/08

(KZD) (unreported)

Maron v Mulbarton Gardens (Pty) Ltd 1975 (4) SA 123 (W)

Marques v Unibank 2001 (1) SA 145 (W)

Weinbren v Michaelides 1957 (1) SA 650 (W)

Fitzgerald v Western Agencies 1968 (1) SA 288 (T)

Marques v Unibank Ltd 2001 (1) SA 145 (W)

Van Niekerk v Favel 2006 (4) SA 548 (W)

Vessels v Brink 1950 (4) SA 352 (T)

\section{List of abbreviations}

CAA Credit Agreements Act

cl clause(s)

NCA National Credit Act

par paragraph(s)

reg regulation(s)

s section(s) 